\title{
PENingkatan kemampuan menulis teks NEGOSIASI DENGAN MODEL PEMBELAJARAN GROUP INUESTIGATIONPADA SISWA KELAS $X$ SMA NEGERI 2 REMBANG
}

\author{
AINUL IBNU NIAM HUDA' TURAHMAT ${ }^{2}$, AIDA AZIZAH ${ }^{3}$ \\ Prodi PBSI, FKIP, Universitas Islam Sultan Agung \\ niampbsi@yahoo.com', lintangsastra@unissula.ac.id², aidaazizah@unissula.ac.id³ \\ Pertama Diterima: 07 Agustus 2017 Bukti Akhir Diterima: 07 Oktober 2017
}

\begin{abstract}
Abstrak
Tujuan penelitian ini adalah mendiskripsikan peningkatkan hasil belajar siswa, sikap belajar siswa, dan motivasi belajar siswa dalam materi menulis teks negosiasi dengan menggunakan model pembelajaran Group Investigation. Desain penelitian yang digunakan dalam penelitian ini adalah Penelitian Tindakan Kelas (PTK). Hasil penelitian menunjukkan 1) keterampilan menulis teks negosiasi siswa kelas X IIS 3 SMA N 2 Rembang setelah mengikuti pembelajaran menulis teks negosiasi dengan model pembelajaran Group Investigation mengalami peningkatan. Peningkatan ini terlihat dari perubahan nilai rata-rata dari siklus I, siklus II dan siklus III. Pada siklus I diperoleh hasil rata-rata sebesar 64,83. Pada siklus II diperoleh hasil rata-rata sebesar 76,54. Pada siklus III diperoleh hasil rata-rata 87,97. Peningkatan terjadi pada setiap siklusnya hingga mencapai hasil yang maksimal pada siklus III yang termasuk dalam kategori sangat baik dan sudah melampaui KKM yaitu 70,0. 2) Sikap belajar siswa mengalami peningkatan di setiap siklus. Pada sikap siklus I sebesar 57,97\% pada siklus II meningkat menjadi $66,09 \%$ dan pada siklus III meningkat menjadi $69,31 \%$. 3) motivasi belajar siswa juga mengalami peningkatan di setiap siklus. Pada siklus I sebesar $60,38 \%$, pada siklus II meningkat menjadi 75,93\%, dan pada siklus III meningkat menjadi 77,5\%.
\end{abstract}

Kata Kunci: menulis teks negosiasi, model pembelajaran group investigation.

\begin{abstract}
This research is aimed to describe the increase of the students result, the attitude of students, and motivation of the students to study in this material using group investigation learning model. The used research design is PTK. The result shows 1) the skill of writing negosiation text grade X IIS 3 SMA N 2 Rembang after using this model is increased. It is shown from te changeof score's average from $1^{\text {st }} \mathrm{cycle}, 2^{\text {nd }} \mathrm{cycle}$, and $3^{\text {rd }} \mathrm{cycle}$. From $1^{\text {st }} \mathrm{cycle}$, it is got that the score's average is 64,83 . In the $2^{\text {nd }}$ cycle, it is 76,54. For the $3^{\text {rd }}$ cycle, it is got 87,97. The increase is happened in each cycle until it got the maximal score in the cycle III which is very good and more than KKM, that is 70,0. 2) The student attitude is getting increase in each cycle. In the $1^{\text {st }}$ cycle, it is $57,97 \%$. In the $2^{\text {nd }}$ cycle, getting increase to $66,09 \%$. And the $3^{\text {rd }}$ cycle, it is getting increase to 69,31\%. 3) The student motivation is also getting increse in every cycle. For the $1^{\text {st }}$ cycle, it is $60,38 \%$, in $2^{\text {nd }}$ cycle, getting increase $75,93 \%$, and the $3^{\text {rd }}$ cycle getting increase to $77,5 \%$
\end{abstract}


Key words: writing negosiation text, group investigation learning model.

\section{PENDAHULUAN}

Menulis merupakan kegiatan yang produktif dan ekspresif (Tarigan 2008, hal 15). Namun, kenyataannya dalam menuangkan sebuah pikiran atau ide yang sistematis dan teratur dalam sebuah tulisan tidaklah mudah. Seringkali apa yang ada dalam pikiran tidak sejalan dengan apa yang dituangkannya dalam tulisan. Memproduksi tulisan tidak akan datang secara otomatis, melainkan harus melalui latihan dan praktik menulis secara teratur. Sehubungan dengan hal tersebut, maka pengajaran menulis harus lebih ditingkatkan.

Selama ini siswa masih menganggap pembelajaran menulis merupakan suatu pembelajaran yang membosankan dan sulit dilakukan. Rasa bosan dan kesulitan yang muncul disebabkan oleh beberapa faktor, secara umum faktor itu terbagi menjadi dua, yaitu faktor internal dan eksternal. faktor internal meliputi minat, motivasi, tingkat kecerdasan dan daya tingkap siswa. Sementara itu, faktor eksternal meliputi faktor lingkungan sekitar, keluarga, pergaulan, kondisi sekolah, dan keadaan kelas.

Berdasarkan hasil observasi dan wawancara kepada guru Bahasa Indonesia yang bernama Ibu Sungatri, M.Pd. yang mengajar kelas X SMA N 2 Rembang, ada beberapa permasalahan yang ditemui oleh guru dalam pembelajaran menulis. Masalah yang dihadapi oleh guru yaitu, siswa menganggap kegiatan menulis susah dilakukan. Kegiatan menulis akan berjalan efektif apabila ditunjang dengan media, buku penunjang, teknologi, informasi atau internet yang memadai. Model pembelajaran yang digunakan oleh guru dalam mengajar menulis juga masih menggunakan model pembelajaran yang konvensional sehingga keaktivan siswa dalam proses pembelajaran menulis masih kurang.

Dunia pendidikan Indonesia sejak adanya pembaharuan kurikulum pada tahun 2013 yang dikenal dengan kurikulum 2013 yang berbasis teks. Hal ini menjadikan keterampilan menulis menjadi sangat penting. Berdasarkan kurikulum 2013, pada kelas X terdapat kompetensi inti 4 mengolah, menalar, dan menyaji dalam ranah konkret dan ranah abstrak terkait dengan pengembangan dari yang dipelajarinya di sekolah secara mandiri, dan mampu menggunakan metoda sesuai kaidah keilmuan. Kompetensi inti tersebut kemudian mengerucut pada kompetensi dasar 4.2 memproduksi teks negosiasi yang koheren sesuai dengan karakteristik teks yang akan 
dibuat baik secara lisan maupun tulisan. Teks negosiasi adalah sebuah teks yang didalamnya berisi bentuk interaksi sosial yang berfungsi untuk mencari penyelesaian bersama di antara pihak-pihak yang mempunyai perbedaan kepentingan. Pihak-pihak tersebut berusaha menyelesaikan perbedaan itu dengan cara-cara yang baik tanpa merugikan salah satu pihak. Contohnya, ketika terjadi kegiatan tawar menawar antara penjual dengan pembeli, maka kegiatan tersebut disebut dengan kegiatan negosiasi. Dalam kurikulum 2013, kegiatan tawar menawar tadi bisa dibuat menjadi sebuah teks yang disebut dengan teks negosiasi. Kompetensi menulis teks negosiasi sangat bermanfaat bagi siswa karena dengan kompetensi tersebut, siswa dapat berpikir untuk menuliskan solusi yang terbaik yang dapat dilakukan dalam suatu kegiatan tertentu melalui diskusi.

Hasil dari wawancara dengan guru Bahasa Indonesia di SMA N 2 Rembang, menunjukkan bahwa teks negosiasi menjadi salah satu teks yang perlu perhatian khusus. Hal tersebut disebabkan siswa belum memahami secara benar tentang teks negosiasi dan siswa kurang menyukai pembelajaran menulis teks negosiasi. SMA N 2 Rembang dipilih sebagai tempat penelitian alasannya yaitu sekolah ini merupakan satu di antara sekolah yang sudah menerapkan kurikulum 2013, sebab teks negosiasi yaitu salah satu teks yang diajarkaran di kurikulum 2013. Selain itu melihat dari akreditasi dan prestasi SMA N 2 Rembang yang termasuk sekolah unggulan di Kabupaten Rembang, serta letak SMA N 2 Rembang yang berada di wilayah Kota Rembang bisa sangat membantu siswa untuk praktik langsung karena di wilayah Kota Rembang terdapat banyak tokotoko dan pasar yang dapat menjadi tempat praktik negosiasi secara langsung.

Guru sebagai penyampai materi kepada siswa harus dapat menyampaikan materi yang akan dibahas dengan metode atau model pembelajaran yang tepat dan menarik. Hal tersebut akan berdampak pada keberhasilan siswa dalam mengikuti pembelajaran dan mengerjakan tugas yang diberikan guru. Salah satu model pembelajaran yang bisa diterapkan adalah model pembelajaran Group Investigation. Menurut Shoimin (2014, hal 108) Group Investigation adalah suatu model pembelajaran yang lebih menekankan pada pilihan dan kontrol siswa daripada menerapkan teknik-teknik pengejaran di ruang kelas.

Group Investigation merupakan salah satu bentuk model pembelajaran kooperatif yang menekankan pada partisipasi dan aktivitas siswa untuk mencari sendiri 
materi (informasi) pelajaran yang akan dipelajari melalui bahan-bahan yang tersedia, misalnya dari buku pelajaran atau siswa dapat mencari melalui internet. Siswa dilibatkan sejak perencanaan, baik dalam menentukan topik maupun cara untuk mempelajarinya melalui investigasi. Tipe ini menuntut para siswa untuk memiliki kemampuan yang baik dalam berkomunikasi maupun dalam keterampilan proses kelompok. Model pembelajaran Group Investigation dapat melatih siswa untuk menumbuhkan kemampuan berfikir mandiri. Keterlibatan siswa secara aktif dapat terlihat mulai dari tahap pertama sampai tahap akhir pembelajaran. Model pembelajaran Group Investigation dapat mendorong siswa belajar lebih aktif dan lebih bermakna. Artinya, siswa dituntut berpikir suatu persoalan dan mencari cara penyelesaiannya sendiri. Oleh karena itu, siswa lebih terlatih untuk menggunakan keterampilan pengetahuannya sehingga pengetahuan dan pengalaman belajar siswa dapat tertanam untuk jangka waktu yang lama. Hasil penelitian menunjukkan bahwa terdapat pengaruh model pembelajaran Group Investigation terhadap kemampuan berpikir kreatif siswa. Pernyataan tersebut senada dengan pendapat Megawati (2013, hal 3) bahwa kemampuan berpikir kreatif siswa yang proses pembelajarannya menggunakan model Group Investigation lebih baik daripada siswa yang proses pembelajarannya menggunakan model pembelajaran klasikal.

Beberapa penelitian lain yang senada dengan penelitian Megawati (2013) mengenai menulis dan model pembelajaran Group Investigation yaitu penelitian Gunersel (2010), Deni et al (2011), Haffidianti (2011), Khan (2011), Javed (2013), Tahriri et al (2013), Alidots (2014), Argareza (2014), Barus et al (2014), Eviyana et al (2014), Akbar et al (2015), Kurhadi (2015), Pinangsari (2015), Setyaningsih (2015), Suandi et al (2015), Bian (2016), dan Septiana et al (2016).

\section{METODE PENELITIAN}

Dalam metode penelitian ini membahas mengenai: (1) desain penelitian, (2) subjek, objek, tempat, dan waktu penelitian, (3) populasi dan sampel, (4) variabel penelitian, (5) prosedur penelitian, (6) instrumen penelitian, (7) teknik pengumpulan data, dan (8) teknik analisis data. 


\section{Desain Penelitian}

Desain penelitian yang digunakan dalam penelitian ini adalah penelitian tindakan kelas (PTK) yaitu penelitian yang dilakukan oleh guru di kelas atau di sekolah tempat ia mengajar dengan penekanan pada penyempurnaan atau peningkatan proses praktik pembelajaran (Arikunto 2014, hal 91). Pengambilan sampel pada umumnya dilakukan dengan pengumpulan data menggunakan instrumen. Selain itu, penelitian ini bersifat deskriptif, sebab menggambarkan bagaimana suatu model pembelajaran dilakukan untuk mencapai hasil yang diinginkan. Untuk mencapai hasil yang diharapkan tersebut, dalam penelitian ini penulis melakukan penelitian tindakan yang bertujuan untuk mengetahui sejauh mana guru sebagai peneliti melaksanakan tugas pokoknya dan apakah pembelajaran berhasil memperbaiki hasil belajar yang kurang baik.

Desain penelitian tindakan kelas ini menggunakan desain Kemmis. Kajian dilaksanakan dengan maksud untuk meningkatkan kemantapan rasional dari tindakantindakan yang dilakukan serta memperbaiki kondisi-kondisi praktik pembelajaran sebelumnya. Tujuan dari penggunaan penelitian tindakan kelas (PTK) adalah untuk meningkatkan kualitas pembelajaran siswa, dalam hal ini yakni keterampilan menyimak untuk menemukan pokok-pokok berita yang didengar.

Praktik pembelajaran tersebut dilakukan dalam siklus tindakan yang terdiri atas empat komponen, yakni (1) perencanaan; (2) tindakan; (3) observasi; dan (4) refleksi. Penelitian tindakan kelas ini dilakukan dalam tiga siklus, yaitu siklus I, siklus II dan siklus III.

\section{Subjek, Objek, Tempat, dan Waktu Penelitian \\ Subjek Penelitian}

Subjek dalam penelitian ini adalah siswa kelas X IIS 3 SMA N 2 Rembang. Peneliti memilih kelas X IIS 3. Jumlah siswa kelas X IIS 3 adalah 32 siswa, yang terdiri atas 20 siswa Perempuan dan 12 siswa laki-laki. karena keterampilan menulis dikelas tersebut belum optimal. masih banyak siswa yang kebingungan saat guru membeikan tugas untuk menulis. Berdasarkan wawancara dengan guru Bahasa Indonesia di SMA N 2 Rembang yang bernama Sungatri, M.Pd. mengatakan bahwa siswa kelas X IIS 3 kesulitan dalam memahami materi teks negosiasi serta saat disuruh menulis teks 
negosiasi. Hal tersebut disebabkan siswa belum memahami secara benar tentang teks negosiasi dan siswa kurang menyukai pembelajaran menulis teks negosiasi.

\section{Objek Penelitian}

Objek penelitian ini adalah kesulitan siswa dalam keterampilan menulis teks negosiasi pada pembelajaran bahasa Indonesia pada siswa kelas X SMA N 2 Rembang.

\section{Tempat Penelitian}

Tempat pelaksanaan penelitian ini adalah di SMA N 2 Rembang.

\section{Waktu Penelitian}

Waktu pelaksanaan penelitian adalah saat semester genap tahun ajaran 2016/2017 kisaran bulan Januari-April 2017.

\section{Populasi dan Sampel}

Populasi adalah wilayah generalisasi yang terdiri atas objek atau subjek yang mempunyai kualitas dan karakteristik tertentu yang ditetapkan oleh peneliti untuk dipelajari dan kemudian ditarik kesimpulan. populasi dalam penelitian ini adalah siswa kelas X SMA N 2 Rembang tahun pelajaran 2016/2017. Secara keseluruhan ada 9 kelas yang ternagi menjadi kelas IPA 1-5 yang berjumlah 160 siswa, Bahasa 1-2 yang berjumlah 64 dan IPS 1-3 yang berjumlah 96, yang total keseluruhannya adalah 320 siswa. Sampel dalam penelitian ini adalah siswa kelas X IIS 3 SMA N 2 Rembang dengan jumlah siswa 32. Peneliti memilih kelas ini karena berdasarkan wawancara dengan Ibu Sungatri, M.Pd. selaku guru mata pelajaran bahasa Indonesia di SMA N 2 Rembang menyarankan untuk melakukan peneliian dikelas tersebut karena kemampuan dan minat siswa dalam menulis masih kurang dibandingkan kelas lain.

\section{Variabel}

Variabel yang digunakan dalam penelitian ini terbagi menjadi dua yakni sebagai berikut.

\section{Variabel Bebas}

Sugiyono (2009, hal 4) mengemukakan variabel bebas adalah variabel yang mempengaruhi atau yang menjadi sebab perubahannya atau timbulnya variabel terikat. variabel bebas dalam penelitian ini meliputi model pembelajaran Group Investigation. 


\section{Variabel Terikat}

Sugiyono (2009, hal 6) mengemukakan variabel terikat adalah variabel yang dipengaruhi atau yang menjadi akibat adanya variabel bebas. Variabel terikat dalam penelitian ini adalah ketrampilan menulis teks negosiasi.

\section{Instrumen Penelitian}

Instrumen penelitian adalah alat atau fasilitas yang digunakan oleh peneliti dalam mengumpulkan data dengan maksud agar pekerjaan yang dilakukan jadi lebih mudah dan hasilnya lebih baik, dalam arti cermat, lengkap, dan sistematis sehingga lebih mudah untuk diolah. Berdasarkan keterangan tersebut dapat disimpulkan bahwa instrumen penelitian adalah alat yang digunakan peneliti untuk mengumpulkan data dengan maksud agar pekerjaannya lebih mudah dan hasilnya lebih sistematis. Instrumen penelitian yang digunakan peneliti dalam penelitian ini adalah instrumen tes dan non tes. Instrumen tes berupa menulis, sedangkan instrumen nontes berupa observasi, angket, wawancara, dan dokumentasi.

\section{Teknik Pengumpulan Data}

Teknik pengumpulan data merupakan langkah yang paling utama dalam penelitian, karena tujuan utama dari penelitian adalah mendapatkan data. Tanpa mengetahui teknik pengumpulan data, maka peneliti tidak akan mendapatkan data yang memenuhi standar data yang ditetapkan (Sugiyono 2010, hal 308). Teknik pengumpulan data pada penelitian ini adalah menggunakan penerapan tes dan non tes.

\section{Teknik Analisis Data}

Teknik analisis data yang digunakan dalam penelitian ini adalah teknik analisis data kuantitaif dan kualitatif.

\section{Analisis Data Kuantitatif}

Analisis data kuantitatif digunakan untuk menganalisis data kuantitaif dengan tujuan mengetahui menulis teks negosiasi setelah menggunakan model pembelajaran Group Investigation. Data tersebut diperoleh dari analisis prasiklus, dibandingkan dengan analisis siklus I, II, dan III untuk mengetahui gambaran presentase peningkatannya. Data yang diperoleh dari hasil tes secara tertulis. Hasil analisis data secara kuantitatif dihitung secara presentase melalui langkah-langkah yakni (1) merekap nilai-nilai yang diperoleh siswa (2) menghitung nilai komulatif dari seluruh aspek (3) menghitung nilai rata-rata (4) menghitung presentase. Hasil perhitungan nilai siswa dari 
masing-masing siklus ini kemudian dibandingkan. Hasilnya akan memberi gambaran menegenai persentase peningkatan keterampilan menulis teks negosiasi.

\section{Analisis Data Kualitatif}

Analisis data kualitatif digunakan untuk menganalisis data kualitatif dan memberikan gambaran perubahan perilaku siswa dalam pembelajaran menulis teks negosiasi dengan menggunakan model pembelajaran Group Investigation. Data kualitatif yang diperoleh dari hasil nontes yaitu observasi, wawancara, jurnal, dan dokumentasi. hasil analisis digunakan untuk mengetahhui peserta didik yang mengalami kesulitan dalam pembelajaran menulis teks negosiasi dengan menggunakan model pembelajaran Group Investigation.

\section{HASIL PENELITIAN DAN PEMBAHASAN}

Pemaparan pembahasan dalam penelitian ini berdasar pada hasil penelitian pada pembahasan di siklus I, siklus II dan siklus III. Data pembahasan ini mengacu dari hasil data tes maupun nontes yang diperoleh siswa dari proses pembelajaran menulis teks negosiasi dengan menggunakan model pembelajaran Group Investigation. Proses Pembelajaran Kemampuan Menulis Teks Negosiasi dengan Menggunakan Model Pembelajaran Group Investigation pada Siswa Kelas X IIS 3 Negeri 2 Rembang

Proses hasil pembelajaran kemampuan menulis teks negosiasi dengan menggunakan model Group Investigation yang dilakukan dalam penelitian ini terdiri dari tiga tahap perencanaan yaitu tahap siklus I, siklus II, dan siklus III.

\section{Siklus I}

Pada kegiatan penelitian tahap siklus I, peneliti ingin mengetahui kemampuan dasar siswa dalam mengerjakan tes menulis teks negosiasi. Oleh karena itu dalam penelitian siklus I ini kegiatan pembelajaran masih menggunakan metode dan model pembelajaran secara konfensional (ceramah). Hasil nilai tes rata-rata yang diperoleh dalam proses pembelajaran kemampuan menulis teks negosiasi pada tahap siklus I ini sebesar 64,44 yang berarti masih di bawah KKM sekolah. Oleh karena itu peneliti melanjutkan pada proses siklus II. 


\section{Siklus II}

Hasil tes pada tahap siklus II merupakan hasil tes siswa setelah mengikuti proses pembelajaran menulis teks negosiasi dengan menggunakan model pembelajaran Group Investigation, baik tes kemampuan menulis teks negosiasi maupun tes sikap dan perilaku siswa selama mengikuti proses pembelajaran menulis teks prosedur. Pada proses pembelajaran ini siswa diarahkan bisa berpikir lebih kritis dan dinamis dalam membuat draf teks negosiasi dan menyusunnya sesuai dengan teks negosiasi yang baik pada masing-masing kelompok diskusi. Hasil nilai tes rata-rata yang diperoleh dalam proses pembelajaran kemampuan menulis teks negosiasi dengan menggunakan model pembelajaran Group Investigation pada siklus II ini sebesar 76,31 (dalam kategori baik) namun sudah ada peningkatan dari hasil tahap siklus I, akan tetapi masih perlu ditingkatkan lagi, sehingga peneliti melanjutkan pada tahap siklus III.

\section{Siklus III}

Penelitian pada siklus III merupakan proses kelanjutan dari tindakan siklus II. Hal ini dilakukan mengingat hasil akhir nilai rata-rata proses pembelajaran menulis teks negosiasi dengan menggunakan model Group Investigation pada tindakan siklus II masih dalam kategori baik yaitu sebesar 76,31. Hasil tersebut dirasa belum memenuhi target sasaran peningkatan nilai pembelajaran dalam penelitian ini yaitu kategori sangat baik, disamping itu pada tahap siklus III peneliti ingin lebih menguatkan perubahan sikap dan perilaku yang sudah baik pada hasil siklus II. Hasil nilai tes rata-rata yang diperoleh dalam proses pembelajaran kemampuan menulis teks negosiasi dengan menggunakan model pembelajaran Group Investigation pada siklus III ini sebesar 88,50 (dalam kategori sangat baik), yang berarti ada peningkatan dari hasil tahap siklus II. Data hasil nontes tahap siklus III didapatkan bahwa kondisi kelas sangat tertib dan ideal untuk melaksanakan proses pembelajaran menulis teks negosiasi.

\section{Peningkatan Hasil Tes Kemampuan Menulis Teks Negosiasi pada Siswa Kelas X IIS 3 SMA Negeri 2 Rembang}

Hasil nilai tes rata-rata yang diperoleh dalam proses pembelajaran kemampuan menulis teks negosiasi dengan menggunakan model pembelajaran Group Investigation, dari tahap sikllus I, siklus II dan siklus III selalu terjadi peningkatan nilai hasil tes kemampuan menulis teks negosiasi dan juga terjadinya peningkatan perubahan sikap 
dan perilaku siswa menuju kearah yang lebih positif. Sehingga hasil nilai tes yang peneliti targetkan dapat dicapai. Berikut adalah pemaparan dan penjelasan hasil tes kemampuan menulis teks prosedur kompleks tiap-tiap siklusnya.

Tabel 1 Hasil Rata-Rata Tiap Aspek Tes Kemampuan Menulis Teks Negosiasi pada Tindakan Siklus I, Siklus II dan Siklus III.

\begin{tabular}{|l|l|c|c|c|}
\hline No & \multicolumn{1}{|c|}{ Aspek } & Siklus I & Siklus II & Siklus III \\
\hline 1 & Kesesuaian Isi dengan judul & 63,48 & 76,49 & 87,5 \\
\hline 2 & $\begin{array}{l}\text { kelengkapan dan keruntutan } \\
\text { struktur }\end{array}$ & 61,92 & 73,88 & 93,75 \\
\hline 3 & Kaidah Kebahasaan & 69,53 & 79,84 & 90,63 \\
\hline 4 & Penggunaan EBI & 64,38 & 75,94 & 80,00 \\
\hline \multicolumn{2}{|c|}{ Jumlah } & $\mathbf{2 5 9 , 3 1}$ & $\mathbf{3 0 6 , 1 5}$ & $\mathbf{3 5 1 , 8 8}$ \\
\hline \multicolumn{2}{|c|}{ Rata-rata } & $\mathbf{6 4 , 8 3}$ & $\mathbf{7 6 , 5 4}$ & $\mathbf{8 7 , 9 7}$ \\
\hline
\end{tabular}

Berdasarkan tabel 1 tersebut dapat diketahui bahwa selalu terjadi peningkatan yang berarti dari tiap tahapan siklus yang satu ke siklus berikutnya. Pada tahap siklus I hasil nilai rata-rata yang diperoleh adalah sebesar 64,83 (kategori nilai cukup) dan terjadi peningkatan pada hasil nilai rata-rata pada tahap siklus II yaitu sebesar 76,54 (kategori nilai baik) sampai akhirnya mencapai nilai tertinggi pada siklus III yaitu sebesar 87,97 (kategori nilai sangat baik).

Tabel 2 Peningkatan Rata-Rata Tes Kemampuan Menulis Teks Negosiasi pada Tindakan Siklus I, Siklus II dan Siklus III.

\begin{tabular}{|c|l|c|}
\hline No & \multicolumn{1}{|c|}{ Siklus } & Rata-rata \\
\hline 1 & Siklus I & 64,83 \\
\hline 2 & Siklus II & 76,54 \\
\hline 3 & Siklus III & 87,97 \\
\hline \multicolumn{2}{|c|}{ Jumlah } & $\mathbf{2 2 9 , 3 4}$ \\
\hline \multicolumn{2}{|c|}{ Rata-rata } & $\mathbf{7 6 , 4 5}$ \\
\hline
\end{tabular}

Berdasarkan tabel 2 tersebut dapat diketahui bahwa nilai rata-rata dari semua siklus, yang meliputi siklus I, siklus II, dan siklus III sebesar 76,45. Dengan rincian yaitu siklus I sebesar 64,83, siklus II sebesar 76,54, dan siklus III sebesar 87,97.

Tabel 3 Peningkatan Rata-Rata Tes Kemampuan Menulis Teks Negosiasi pada Tindakan Siklus I, Siklus II dan Siklus III.

\begin{tabular}{|l|l|c|c|c|}
\hline \multirow{2}{*}{ No } & Aspek & \multicolumn{3}{|c|}{ Peningkatan } \\
\cline { 3 - 5 } & & S1-S2 & S2-S3 & S1-S3 \\
\hline 1 & Kesesuaian Isi dengan judul & 13,01 & 10,92 & 23,93 \\
\hline
\end{tabular}




\begin{tabular}{|l|l|c|c|c|}
\hline 2 & $\begin{array}{l}\text { kelengkapan dan keruntutan } \\
\text { struktur }\end{array}$ & 11,96 & 19,79 & 31,75 \\
\hline 3 & Kaidah Kebahasaan & 10,31 & 10,79 & 21,1 \\
\hline 4 & Penggunaan EBI & 11,56 & 4,06 & 15,62 \\
\hline \multicolumn{2}{|c|}{ Jumlah } & 46,84 & 45,56 & 92,4 \\
\hline \multicolumn{2}{|c|}{ Rata-rata } & 11,71 & 11,39 & 23,1 \\
\hline
\end{tabular}

Berdasarkan tabel 3 tersebut dapat diketahui bahwa terjadi peningkatan kemampuan menulis teks negosiasi dengan menggunakan model pembelajaran Group Investigation yang sangat berarti dari tahapan siklus I (sebelum tindakan) ke siklus III (setelah beberapa tindakan) yaitu sebesar rata-rata 23,1. Peningkatan terjadi dari tahapan siklus I ke siklus II sebesar 11,71. Sedangkan dari siklus II ke siklus III mengalami peningkatan sebesar 11,39.

\section{Perubahan Sikap dan Motivasi Belajar Siswa Kelas X IIS 3 SMA N 2 Rembang terhadap Pembelajaran Menulis Teks Negosiasi dengan Menggunakan Model Pembelajaran Group Investigation.}

Berdasarkan hasil analisis data nontes yang dilakukan dapat dijelaskan bahwa sikap dan motivasi belajar siswa dalam proses pembelajaran menulis teks negosiasi menunjukkan adanya perubahan yang selalu meningkat kearah yang lebih baik dari siklus yang satu ke siklus yang berikutnya. Secara umum peningkatan perubahan siswa tersebut adalah siswa semakin menunjukkan sikap semangat, serius, motivasi tinggi, tertib dan disiplin dalam mengikuti proses pembelajaran menulis teks negosiasi. Suasana kelas yang pada tahap siklus I masih kurang tertib dan kurang kondusif untuk proses pembelajaran, pada siklus II dan III suasana kelas sudah jauh lebih baik, lebih tertib dan lebih kondusif untuk proses pembelajaran menulis teks negosiasi. Di samping itu keaktifan siswa yang pada tahap siklus I terlihat kurang aktif dalam proses pembelajaran, pada siklus II dan III sudah berubah menjadi siswa yang aktif, mereka semakin aktif bertanya dan menanggapi pendapat teman yang lain dalam proses pembelajaran menulis teks negosiasi. Di samping itu siswa tidak lagi merasa jenuh dan bosan dalam mengikuti proses pembelajaran menulis teks negosiasi karena guru sudah bervariatif dalam pelaksanaan proses pembelajaran dengan menerapkan model pembelajaran Group Investigation.

Perubahan sikap dan perilaku siswa kearah positif dan lebih baik berpengaruh besar terhadap hasil tes kemampuan siswa dalam proses pembelajaran menulis teks 
negosiasi, hal ini dapat dibuktikan melalui data tes yang selalu meningkat dari tiat-tiap tahapan siklus yang dilakukan, yaitunilai rata-rata pada siklus I sebesar 64,83, nilai rata-rata pada siklus II sebesar 76,54, dan nilai rata-rata pada siklus III sebesar 87,97. Hal ini merupakan bukti keberhasilan penerapan model pembelajaran Group Investigation pada pembelajaran menulis teks negosiasi pada siswa kelas X IIS 3 SMA N 2 Rembang.

Penerapan model pembelajaran Group Investigation pada pembelajaran menulis teks negosiasi pada siswa kelas X IIS 3 SMA N 2 Rembang memberikan kemudahan dalam proses pembelajaran menulis teks negosiasi, menambah pengetahuan dan pengalaman siswa, menambah keaktifan dan kreatifitas siswa serta kedisiplinan siswa. Di samping itu dengan model pembelajaran Group Investigation pada pembelajaran menulis teks negosiasi pada siswa kelas X IIS 3 SMA N 2 Rembang menjadi lebih menyenangkan, siswa menjadi lebih bersemangat, lebih fokus dan menarik, sehingga proses pembelajaran menjadi tidak membosankan. model pembelajaran Group Investigation pada pembelajaran menulis teks negosiasi pada siswa kelas $\mathrm{X}$ IIS 3 SMA N 2 Rembang mampu mengangkat motivasi dan merangsang kerja otak siswa untuk mampu menulis teks negosiasi dengan baik dan benar. Hal ini karena siswa dituntut untuk bisa berpikir lebih aktif dalam melakukakan investigasi di kelompok.

Berikut peneliti sajikan hasil perbandingan data nontes (hasil observasi, angket siswa dan dokumentasi foto) dari setiap siklus (siklus I, siklus II dan siklus III) dalam bentuk tabel.

Tabel 4 Hasil Penilaian Observasi Sikap Siklus I, Siklus II dan Siklus III

\begin{tabular}{|c|c|c|c|c|c|c|c|}
\hline \multirow[b]{3}{*}{ No } & \multirow{3}{*}{ Aspek Observasi } & \multicolumn{6}{|c|}{ Rata-rata } \\
\hline & & \multicolumn{2}{|c|}{ Siklus I } & \multicolumn{2}{|c|}{ Siklus II } & \multicolumn{2}{|c|}{ Siklus III } \\
\hline & & $\mathbf{F}$ & $\%$ & $\mathbf{F}$ & $\%$ & $\mathbf{F}$ & $\%$ \\
\hline 1 & $\begin{array}{l}\text { Siswa tidak terlambat } \\
\text { masuk kelas }\end{array}$ & 28 & 87,5 & 28 & 87,5 & 32 & 100 \\
\hline 2 & $\begin{array}{lr}\text { Siswa saling } & \text { membantu } \\
\text { menjelaskan } & \text { dengan } \\
\text { teman } & \end{array}$ & 15 & 46,88 & 22 & 68,75 & 28 & 87,5 \\
\hline 3 & $\begin{array}{l}\text { Siswa bertanya jawab } \\
\text { dengan guru apabila } \\
\text { menemukan permasalahan }\end{array}$ & 15 & 46,88 & 20 & 62,5 & 25 & 78,13 \\
\hline 4 & $\begin{array}{l}\text { Siswa antusias saat } \\
\text { pembelajaran }\end{array}$ & 15 & 46,88 & 22 & 68,75 & 28 & 87,5 \\
\hline
\end{tabular}




\begin{tabular}{|l|l|l|l|l|l|l|l|}
\hline 5 & $\begin{array}{l}\text { Siswa tidak tidur dan } \\
\text { ngobrol sendiri saat } \\
\text { pembelajaran }\end{array}$ & 28 & 87,5 & 30 & 93,75 & 32 & 100 \\
\hline 6 & $\begin{array}{l}\text { siswa tidak membuat } \\
\text { gaduh dan mengganggu } \\
\text { proses KBM }\end{array}$ & 22 & 68,75 & 22 & 68,75 & 25 & 78,13 \\
\hline 7 & $\begin{array}{l}\text { Siswa tidak membolos di } \\
\text { saat pembelajaran }\end{array}$ & 32 & 100 & 32 & 100 & 32 & 100 \\
\hline 8 & $\begin{array}{l}\text { Siswa mengerjakan tugas } \\
\text { dari guru tepat waktu }\end{array}$ & 11 & 34,38 & 20 & 62,5 & 26 & 81,25 \\
\hline 9 & $\begin{array}{l}\text { Siswa tidak makan dan } \\
\text { minum di kelas saat } \\
\text { pembelajaran } \\
\text { berlangsung, }\end{array}$ & 62,5 & 28 & 87,5 & 32 & 100 \\
\hline 10 & $\begin{array}{l}\text { Siswa tidak bermain hp } \\
\text { saat pembelajaran }\end{array}$ & 20 & 62,5 & 25 & 78,13 & 30 & 93,75 \\
\hline Jumlah & 206 & 643,77 & 249 & 777,53 & 290 & 906,26 \\
\hline Rata-rata & 20,6 & 64,38 & 24,9 & 77,75 & 29 & 90,63 \\
\hline
\end{tabular}

Berdasarkan tabel 4 tersebut dapat diketahui bahwa hasil observasi sikap siswa pada tiap-tiap tindakan siklus selalu meningkat, yaitu pada siklus I sebesar 64,38\%, pada siklus II meningkat menjadi sebesar 77,13\%, dan pada siklus III meningkat menjadi sebesar 90,01\%.

Observasi sikap ini mengggunakan penilaian positif, jadi semakin banyak siswa yang melakukan semakin bagus. Aspek siswa tidak membolos saat pembelajaran stabil dari siklus I, II, dan III yaitu 32 siswa atau 100\%. Selain aspek tersebut aspek yang lain mengalami peningkatan dari setiap siklusnya.

Secara keseluruhan dari hasil observasi semua siklus sikap siswa mengalami peningkatan setelah diterapkannya model pembelajaran Group Investigation yaitu pada siklus II dan III pada pembelajaran menulis teks negosiasi pada siswa kelas X SMA N 2 Rembang.

Perubahan peningkatan juga terjadi pada hasil observasi motivasi siswa, dimana pada tiap siklusnya mengalami peningkatan, sebagaimana dapat dilihat pada tabel berikut ini. 
Tabel 5 Hasil Penilaian Observasi motivasi Siklus I, Siklus II dan Siklus III

\begin{tabular}{|c|c|c|c|c|c|c|c|}
\hline \multirow{3}{*}{ No } & \multirow{3}{*}{ Aspek Observasi } & \multicolumn{6}{|c|}{ Rata-rata } \\
\hline & & \multicolumn{2}{|c|}{ Siklus I } & \multicolumn{2}{|c|}{ Siklus II } & \multicolumn{2}{|c|}{ Siklus III } \\
\hline & & $\mathbf{F}$ & $\%$ & $\mathbf{F}$ & $\%$ & $\mathbf{F}$ & $\%$ \\
\hline 1 & $\begin{array}{l}\text { Siswa bersemangat } \\
\text { mengikuti } \\
\text { pembelajaran }\end{array}$ & 23 & 71,88 & 28 & 87,50 & 28 & 87,50 \\
\hline 2 & $\begin{array}{l}\text { Siswa senang dengan } \\
\text { materi }\end{array}$ & 22 & 68,75 & 22 & 68,75 & 30 & 93,75 \\
\hline 3 & $\begin{array}{l}\text { Siswa berminat } \\
\text { dengan pelajaran }\end{array}$ & 22 & 68,75 & 23 & 71.88 & 25 & 78,13 \\
\hline 4 & $\begin{array}{lr}\text { Siswa } & \text { merasa } \\
\text { tertantang } & \text { dengan } \\
\text { materi } & \text { yang } \\
\text { disampaikan } & \\
\end{array}$ & 21 & 65,63 & 26 & 81,25 & 29 & 90,63 \\
\hline 5 & $\begin{array}{l}\text { Siswa terlihat tertarik } \\
\text { dengan materi yang } \\
\text { disampaikan }\end{array}$ & 16 & 50,00 & 16 & 50,00 & 28 & 87,50 \\
\hline 6 & $\begin{array}{l}\text { Siswa merasa tugas } \\
\text { bisa dikerjakan }\end{array}$ & 15 & 46,875 & 28 & 87,50 & 28 & 87,50 \\
\hline 7 & $\begin{array}{l}\text { Rasa ingin tahu siswa } \\
\text { tumbuh }\end{array}$ & 16 & 50,00 & 29 & 90,63 & 29 & 90,63 \\
\hline 8 & $\begin{array}{l}\text { Siswa merasa } \\
\text { bahagia } \\
\text { menyelesaikan } \\
\text { dengan berhasil } \\
\text { dalam pembelajaran } \\
\text { ini }\end{array}$ & 23 & 71,88 & 32 & 100,00 & 32 & 100,00 \\
\hline 9 & $\begin{array}{ll}\begin{array}{l}\text { Siswa percaya diri } \\
\text { pada }\end{array} & \text { saat } \\
\text { pembelajaran } & \\
\end{array}$ & 16 & 50,00 & 21 & 65,63 & 28 & 87,50 \\
\hline 10 & $\begin{array}{l}\text { Siswa tidak malu saat } \\
\text { pembelajaran }\end{array}$ & 16 & 50,00 & 21 & 65,63 & 25 & 78,13 \\
\hline \multicolumn{2}{|c|}{ Jumlah } & 190 & 593,77 & 246 & 768,77 & 282 & 881,27 \\
\hline \multicolumn{2}{|c|}{ Rata-rata } & 19 & 59,38 & 24,6 & 76,88 & 28,2 & 88,13 \\
\hline
\end{tabular}

Berdasarkan tabel 5 tersebut dapat diketahui bahwa hasil observasi motivasi siswa pada tiap-tiap tindakan siklus selalu meningkat, yaitu pada siklus I sebesar $59,38 \%$ pada siklus II meningkat menjadi sebesar $76,88 \%$ dan pada siklus III meningkat menjadi sebesar $88,13 \%$. Observasi motivasi ini mengggunakan penilaian 
positif, jadi semakin banyak siswa yang melakukan semakin bagus. Secara keseluruhan dari hasil observasi motivasi siswa semua siklus mengalami peningkatan setelah diterapkannya model pembelajaran Group Investigation pada pembelajaran menulis teks negosiasi pada siswa kelas X SMA N 2 Rembang.

Perubahan peningkatan yang sama terjadi pula pada hasil angket sikap dan motivasi belajar siswa, dimana pada tiap siklusnya terjadi peningkatan yang positif, sebagaimana dapat dilihat pada tabel berikut.

Tabel 6 Hasil Rata-Rata Tiap Aspek Angket Sikap Belajar Siswa pada

Tindakan Siklus I, Siklus II dan Siklus III

\begin{tabular}{|c|c|c|c|c|c|c|c|}
\hline \multirow{3}{*}{ No } & \multirow{3}{*}{$\begin{array}{c}\text { Rentang } \\
\text { Nilai }\end{array}$} & \multicolumn{6}{|c|}{ Rata-rata } \\
\hline & & \multicolumn{2}{|c|}{ Siklus I } & \multicolumn{2}{|c|}{ Siklus II } & \multicolumn{2}{|c|}{ Siklus III } \\
\hline & & $\mathbf{F}$ & $\%$ & $\mathbf{F}$ & $\%$ & $\mathbf{F}$ & $\%$ \\
\hline 1 & $86-100$ & 0 & 0 & 0 & 0 & 0 & 0 \\
\hline 2 & $75-85$ & 0 & 0 & 10 & 773 & 15 & 1174 \\
\hline 3 & $65-74$ & 8 & 560 & 17 & 1064 & 15 & 932 \\
\hline 4 & $51-64$ & 22 & 1203 & 5 & 278 & 2 & 112 \\
\hline \multirow[t]{3}{*}{5} & $0-50$ & 2 & 92 & 0 & 0 & 0 & 0 \\
\hline & Jumlah & 32 & 1855 & 32 & 2115 & 32 & 2218 \\
\hline & Rata-rata $\%$ & & 57,97 & & 66,09 & & 69,31 \\
\hline
\end{tabular}

Berdasarkan tabel 6 tersebut dapat disimpulkan bahwa hasil angket sikap belajar siswa pada tiap-tiap tindakan siklus selalu mengalami peningkatan persentasenya, yang berarti telah terjadinya perubahan sikap belajar siswa kearah positif, yaitu pada siklus I sebesar 57,97\% pada siklus II meningkat menjadi sebesar 66,09\% dan pada siklus III meningkat menjadi sebesar 69,31\%. Hal ini membuktikan bahwa sikap belajar siswa setelah terjadinya tindakan pada setiap siklus menunjukkan adanya perubahan yang berarti dan hali ini dapat menjadikan kondisi yang ideal dan sangat mendukung untuk proses pembelajaran menulis teks negosiasi, yang pada akhirnya dapat meningkatkan nilai tes kemampuan menulis teks negosiasi.

Tabel 7 Hasil Rata-Rata Tiap Aspek Angket Motivasi Belajar Siswa pada Tindakan Siklus I, Siklus II dan Siklus III

\begin{tabular}{|c|c|c|c|c|c|c|c|}
\hline \multirow{3}{*}{ No } & \multirow{3}{*}{$\begin{array}{c}\text { Rentang } \\
\text { Nilai }\end{array}$} & \multicolumn{6}{|c|}{ Rata-rata } \\
\hline & & \multicolumn{2}{|c|}{ Siklus I } & \multicolumn{2}{|c|}{ Siklus II } & \multicolumn{2}{|c|}{ Siklus III } \\
\hline & & $\mathbf{F}$ & $\%$ & $\overline{\mathbf{F}}$ & $\%$ & $\mathbf{F}$ & $\%$ \\
\hline 1 & $86-100$ & 0 & 0 & 2 & 177 & 5 & 439 \\
\hline
\end{tabular}




\begin{tabular}{|l|l|l|l|l|l|l|l|}
\hline 2 & $75-85$ & 0 & 0 & 26 & 1989 & 25 & 1909 \\
\hline 3 & $65-74$ & 12 & 817 & 4 & 264 & 2 & 132 \\
\hline 4 & $51-64$ & 20 & 1115 & 0 & 0 & 0 & 0 \\
\hline 5 & $0-50$ & 0 & 0 & 0 & 0 & 0 & 0 \\
\hline & Jumlah & 32 & 1932 & 32 & 2430 & 32 & 2480 \\
\hline & Rata-rata \% & & 60,38 & & 75,93 & & 77,5 \\
\hline
\end{tabular}

Berdasarkan tabel 7 tersebut dapat disimpulkan bahwa hasil angket motivasi belajar siswa pada tiap-tiap tindakan siklus selalu mengalami peningkatan frekuensi dan persentasenya, yang berarti telah terjadinya perubahan sikap belajar siswa kearah positif, yaitu pada siklus I sebesar $60,38 \%$ pada siklus II meningkat sebesar $75,93 \%$ dan pada siklus III meningkat menjadi sebesar 77,5\%. Hal ini membuktikan bahwa motivasi belajar siswa setelah terjadinya tindakan pada setiap siklus menunjukkan adanya perubahan yang berarti sehingga dapat mencapai kondisi yang ideal dan sangat mendukung untuk proses pembelajaran menulis teks negosiasi, yang pada akhirnya dapat meningkatkan nilai tes kemampuan menulis teks negosiasi.

Dari data observasi sikap dan motivasi maupun data angket sikap dan motivasi belajar siswa dapat ditarik kesimpulan bahwa penggunaan model pembelajaran Group Investigation dapat membuat siswa bertambah semangat, motivasi, kesungguhan, kedisiplinan, ketertiban dan pemahaman serta penguasaan siswa terhadap materi pembelajaran menulis teks negosiasi khususnya di kelas X IIS 3 SMA N 2 Rembang.

Perubahan yang positif pada siswa juga dapat dilihat dari data dokumentasi siswa selama pembelajaran berlangsung. Data dokumentasi foto adalah data visual keberhasilan proses pembelajaran menulis teks negosiasi. Melalui dokumentasi foto siswa dapat dilihat peningkatan perilaku siswa saat proses pembelajaran. Melalui dokumentasi juga bisa dilihat betapa antusias dan seriusnya siswa dalam mengikuti proses pembelajaran menulis teks negosiasi setelah menggunakan model pembelajaran Group Investigation.

Tidak hanya angket, observasi, dan dokumentasi, perubahan yang positif juga dapat dilihat dari data wawancara siswa yang meliputi tiga aspek yaitu aspek sikap, motivsi dan hasil belajar. Melalui wawancara yang dilakukan dari siklus I sampai siklus III dapat diketahui bahwa sikap, motivasi, dan hasil belajar siswa selalu mengalami peningkatan dari tiap siklusnya. Hal ini menunjukkan bahwa model pembelajran Group Investigation sangat berperan penting terhadapa keberhasilan 
proses pembelajaran menulis teks negosiasi pada siswa kelas $\mathrm{X}$ IIS 3 SMA N 2 Rembang .

Dengan demikian dapat disimpulkan bahwa proses pembelajaran menulis teks negosiasi dengan menggunakan model pembelajaran Group Investigation, dapat

membuat siswa bertambah semangat, motivasi, kesungguhan, kedisiplinan dan pemahaman serta penguasaan siswa terhadap pembelajaran menulis teks negosiasi pada siswa kelas X IIS 3 SMA N 2 Rembang. Peningkatan perubahan sikap belajar dan motivasi belajar siswa kearah yang lebih positif dan lebih baik berpengaruh besar terhadap kesiapan, ketertiban, motivasi dan kesungguhan siswa dalam menerima proses pembelajaran menulis teks negosiasi, yang pada akhirnya dapat meningkatkan nilai tes kemampuan menulis teks negosiasi.

\section{PENUTUP}

Berdasarkan rumusan masalah, hasil penelitian dan pembahasan penelitian tindakan kelas ini dapat disimpulkan sebagai berikut.

1. Keterampilan menulis teks negosiasi siswa kelas X IIS 3 SMA N 2 Rembang setelah mengikuti pembelajaran menulis teks negosiasi dengan model pembelajaran Group Investigation mengalami peningkatan. Peningkatan ini terlihat dari perubahan nilai rata-rata dari siklus I, siklus II dan siklus III. Pada siklus I diperoleh hasil rata-rata sebesar 64,83. Pada siklus II diperoleh hasil rata-rata sebesar 76,54. Pada siklus III diperoleh hasil rata-rata 87,97. Peningkatan terjadi pada setiap siklusnya hingga mencapai hasil yang maksimal pada siklus III yang termasuk dalam kategori sangat baik dan sudah melampaui KKM yaitu 70,0.

2. Perubahan sikap siswa kelas X IIS 3 SMA N 2 Rembang setelah mengikuti pembelajaran menulis teks negosiasi dengan model pembelajaran Group Investigation mengalami peningkatan setiap tahapan siklusnya. Diharapkan siswa bisa lebih aktif dan diarahkan kearah yang positif. Pada angket sikap tahap siklus I sebesar 57,97\% pada siklus II meningkat menjadi sebesar 66,09\% dan pada siklus III meningkat menjadi sebesar $69,31 \%$. Perubahan sikap siswa dari siklus I ke siklus II mengalami peningkatan sebesar $8,12 \%$. Sementara itu perubahan sikap siswa dari siklus II ke siklus III juga mengalami peningkatan sebesar 3,22\%. 
3. Perubahan motivasi siswa kelas X IIS 3 SMA N 2 Rembang setelah mengikuti pembelajaran menulis teks negosiasi dengan model pembelajaran Group Investigation mengalami peningkatan setiap tahapan siklusnya. Pada angket motivasi siklus I sebesar 60,38\% pada siklus II meningkat sebesar 75,93\% dan pada siklus III meningkat menjadi sebesar 77,5\%. Perubahan motivasi siswa dari siklus I ke siklus II mengalami peningkatan sebesar $15,55 \%$. Sementara itu perubahan sikap siswa dari siklus II ke siklus III juga mengalami peningkatan sebesar 1,57\%.

\section{DAFTAR PUSTAKA}

Akbar, Akbar et al. (2015). The Efectiveness of Rhetoric-Based Essay Writing Teaching Model with Contextual Approach. International Journal of Language Education and Culture Review, 1 (1): 21-30.

Alidoost, et al. (2014). A Genre-Based Teaching Approach To Academic Writing: Describing Visually Presented Information In Graphs And Charts. International Journal of Language Learning and Applied Linguistics World (IJLLALW), 5 (2): 97-104.

Argareza, Yanuardhani. (2014). Penerapan Model Pembelajaran Group Investigation untuk Meningkatkan Prestasi Belajar IPA Materi Perubahan Kenampakan Permukaan Bumi dan Benda Langit Kelas IV SDN 2 Kajar. Skripsi. Kudus. Universitas Muria Kudus.

Arikunto, Suharsimi. (2010). Prosedur Penelitian. Yogyakarta: Rineka Cipta.

Barus, Sanggup et al. (2014). Pengaruh Media Audiovisual Terhadap Kemampuan Menulis Teks Negosiasi oleh Siswa Kelas X Sma Negeri 1 Dolok Masihul Tahun Pembelajaran 2014/2015. Skripsi. Medan. Universitas Negeri Medan.

Bian, Xiaoyun. (2016). Chinese Efl Undergraduates' Academic Writing: Rhetorical Difficulties And Suggestions. Writing Indonesian Journal of Applied Linguistics, 6(1): 20-29.

Deni et al. (2011). "Peer-editing Practice in the Writing Classrom : Benefits and Drawbacks". Advances in Language and Literaty Studies, 2(1):94.

Eviyana, Kalisa et al. (2014). Pembelajaran Menulis Teks Negosiasi Siswa Kelas X SMA N 1 Pringsewu. Jurnal Kata, 6(1): 1-14. 
Gunersel, Adalet Baris. (2010). Improvement in Writing and Reviewing Skills with Calibrated Peer Review. International Journal for the Scholarship of Teaching and Learning, 3(2):1-15.

Haffidianti, Yunita. (2011). Penerapan Model Pembelajaran Group Investigation (Gi) Dalam Upaya Meningkatkan Hasil Belajar Peserta Didik Pada Materi Pokok Bangun Ruang Kelas VIII F Mts Negeri 1 Semarang Tahun Pelajaran 2010/2011. Skripsi. Semarang. UIN Walisongo.

Javed, Muhammad et al. (2013). Study of Students' Assessment in Writing Skills of the English Language. International Journal of Instruction, 6(2): 1-9.

Khan, Humaira. (2011). "Testing Creative Writing in Pakistan: Tensions and Potential in Classroom Practice". International Journal of Humanities and Social Science, 1(15): 10-22.

Kurhadi, Syarifah. (2015). Peningkatan Keterampilan Menulis Teks Negosiasi dengan Menggunakan Model Jigsaw pada Siswa SMA. Jurnal Rekayasa, 8(1): 1-14.

Pinangsari, Silviana. (2015). Peningkatan Keterampilan Menulis Teks Negosiasi dengan Menggunakan Strategi Pembelajaran Berbasis Masalah Pada Siswa Kelas X Teknik Konstruksi Batu dan Beton SMK Negeri 1 Purworejo. Skripsi. Universitas Negeri Yogyakarta.

Septiana, et al. (2016). Corrective Feedback And Writing Accuracy Of Students Across Different Levels Of Grammatical Sensitivity. Indonesian Journal of Applied Linguistics, 6(1): 1-11.

Setyaningsih, Eri. (2016). Peningkatan Kemampuan Menulis Teks Negosiasi Pengalaman Melalui Metode Group Investigation Pada Siswa Kelas X Mia 1 SMA Negeri 2 Sukoharjo Tahun Ajaran 2015/2016. Skripsi. Surakarta. Universitas Sebelas Maret.

Shoimin, Aris. (2014). 68 Model Pembelajaran Inovatif dalam Kurikulum 2013. Yogyakarta: AR-Ruzz Media.

Suandi, I Nengah, et al. (2015). "Implementasi Pembelajaran Menulis Teks Negosiasi Berdasarkan Kurikulum 2013 Di Kelas X.B Akuntansi SMK Negeri 1 Singaraja”. e-Journal Jurusan Pendidikan Bahasa dan Sastra Indonesia, Undiksha 3(1):1-12.

Sugiyono. (2010). Metode Penelitian Pendidikan. Bandung: Alfabeta. 
Tahriri, Abdorreza et al. (2014)."The Effect of Portfolio Assessment on Learning Idioms in Writing". International Journal of Education \& Literacy Studies. 2 (2): $1-12$.

Tarigan, Henry Guntur. (2008). Menulis sebagai Suatu Keterampilan Berbahasa. Bandung: Angkasa. 